\title{
Preventing HHV-8 transmission and Kaposi's sarcoma (KS) risk prediction and prognostication in resource-poor countries
}

\author{
Amos Mwakigonja ${ }^{1,2^{*}}$, Pawan Pyakurel ${ }^{2}$, Fatemeh Pak ${ }^{2}$, Parviz Kokhaei ${ }^{2}$, Peter Biberfeld ${ }^{2}$, Ephata Kaaya ${ }^{1,2}$ \\ From $12^{\text {th }}$ International Conference on Malignancies in AIDS and Other Acquired Immunodeficiencies \\ (ICMAOI) \\ Bethesda, MD, USA. 26-27 April, 2010
}

\section{Background}

Kaposi's sarcoma (KS) is the now most important AIDS-defining malignancy in sub-Saharan Africa including Tanzania, and human herpesvirus-8 (HHV-8) is necessary for its development. Detecting HHV-8 in biopsies and its antibodies in sera allows the confirmation of KS diagnosis and predicts its risk among blood transfusion (BT) and organ transplant recipients but this is not yet routine in most African countries. This impedes the provision of safe $\mathrm{BT} /$ organ donation as well as KS prevention. A cost-effective HHV-8 serological assay for routine use will help improve blood/organ safety and lower iatrogenic KS incidence in resourcepoor countries.

\section{Materials and methods}

Consecutive archival (1990-2001) biopsies and their corresponding sera from African patients with KS, non-KS tumors, and non-neoplastic (reactive) lesions at Muhimbili National Hospital (MNH) were evaluated by histopathology, immunohistochemistry (IHC) for the HHV-8 latency-associated nuclear antigen (LANA), and serology for HIV and HHV-8 (ELISA) as well as for HHV-8 [immunofluorescence (IFA)].

\section{Results}

A total of 184 biopsies and corresponding sera from 120 KS (65\%), 24 non-KS tumors (13\%), and 40 non-neoplastic lesions (22\%) were evaluated. Most sera $(89.0 \%$, $164 / 184$ ) were HHV-8+ by either IFA or ELISA

\footnotetext{
*Correspondence: rodgeramos@yahoo.com

${ }^{1}$ Department of Pathology, Muhimbili University of Health and Allied

Sciences, Dar es Salaam, Tanzania

Full list of author information is available at the end of the article
}

$\left(\mathrm{p}<0.001\right.$, highly statistically significant, $\left.\mathrm{Chi}^{2} \mathrm{Test}\right)$ and as expected the majority $(68.3 \%, 112 / 164)$ were KS. HHV-8 serology tests by IFA and ELISA were mostly $(92.4 \%, 73 / 79)$ concordant. Sensitivity, positive predictive value (PPV), and specificity were $98.6 \%, 93.5 \%$, and $16.7 \%$ for IFA and $93.5 \%, 98.6 \%$, and $50.0 \%$ for ELISA, respectively. All patients with early-stage KS were HHV8 seropositive but two late-stage cases were seronegative despite LANA expression in their corresponding biopsies.

\section{Conclusions}

HHV-8 frequency at MNH appears to be very high and necessitates routine screening of blood/organ donors and recipients to prevent viral transmission and lower risk of iatrogenic KS development. IFA and ELISA serology tests appeared highly concordant and ELISA showed higher PPV and specificity in detecting antiHHV-8 antibodies. Thus ELISA might allow affordable HHV-8 screening in resource-poor countries like Tanzania, with most lacking the cell culture and fluorescence microscopy facilities needed in IFA. The apparent tissue (LANA)-serum HHV-8 antibodies discrepancy in latestage KS suggests that serum HHV-8 might not be a good indicator of this tumor's development.

\section{Acknowledgements}

These studies were supported by Sida/SAREC of Sweden.

This article has been published as part of Infectious Agents and Cancer Volume 5 Supplement 1, 2010: Proceedings of the $12^{\text {th }}$ International Conference on Malignancies in AIDS and Other Acquired Immunodeficiencies (ICMAOI). The full contents of the supplement are available online at http://www.biomedcentral.com/1750-9378/5?issue=S1. 


\section{Author details}

1Department of Pathology, Muhimbili University of Health and Allied

Sciences, Dar es Salaam, Tanzania. 'Department of Oncology-Pathology,

Karolinska University Hospital Solna/Karolinska Institutet, Stockholm, Sweden.

Published: 11 October 2010

doi:10.1186/1750-9378-5-S1-A66

Cite this article as: Mwakigonja et al.: Preventing HHV-8 transmission

and Kaposi's sarcoma (KS) risk prediction and prognostication in

resource-poor countries. Infectious Agents and Cancer 2010 5(Suppl 1):A66.

Submit your next manuscript to BioMed Central and take full advantage of:

- Convenient online submission

- Thorough peer review

- No space constraints or color figure charges

- Immediate publication on acceptance

- Inclusion in PubMed, CAS, Scopus and Google Scholar

- Research which is freely available for redistribution

Submit your manuscript at www.biomedcentral.com/submit

C Biomed Central 